\title{
Kallis utaretulehdus
}

Anna-Maija Heikkilä ${ }^{1)}$, Jouni Nousiainen ${ }^{2)}$ ja Satu Pyörälä ${ }^{3)}$

${ }^{1)}$ MTT, Taloustutkimus, Luutnantintie 13, 00410 Helsinki, anna-maija.heikkila@mtt.fi

${ }^{2)}$ MTT, Biotekniikka- ja elintarviketutkimus, 31600 Jokioinen, jouni.nousiainen@mtt.fi

${ }^{3)}$ Helsingin yliopisto, Eläinlääketieteellinen tiedekunta, Kliinisen tuotantoeläinlääketieteen laitos, Paroninkuja 20,04920 Saarentaus, satu.pyorala@helsinki.fi

\section{Tiivistelmä}

Utaretulehdus on Suomessa yleisin lypsylehmien poiston syy; kaikista poistoista tehdään utaretulehduksen vuoksi runsas viidennes. Utaresairauksista kertyy myös eniten hoitomerkintöjä, niin ikään noin viidennes kaikista hoidoista. Lypsylehmien yksittäisistä sairauksista äkillinen utaretulehdus on yleisin. Utaretulehdus aiheuttaa maidontuottajalle taloudellisia menetyksiä hoitokustannusten, tuotosmenetysten, lisätyön ja ennenaikaisten poistojen kautta. Tämän tutkimuksen tavoitteena oli määrittää arvot näille menetyksille sekä ratkaista, milloin sairastunut lehmä kannattaa hoitaa ja milloin vastaavasti korvata uudella eläimellä.

Tutkimusmenetelmänä oli dynaaminen optimointi. Tutkimusaineisto optimointimallin muuttujien määrittämiseksi kerättiin ProAgrian seuranta-aineistoista, hintatilastoista ja aikaisemmista tutkimuksista. ProAgrian aineisto käsitti ajanjakson 1.9.2003-31.8.2005 ja sisälsi tiedot lehmien poistoista, poiston syistä ja utaretulehdukseen liittyvistä hoitomerkinnöistä. Aineistossa oli mukana 69490 ayrshirelehmää ja 22789 holstein-friisiläislehmää. Aikaisempia tutkimustuloksia hyödynnettiin muun muassa lehmien tuotosten ennustamisessa ja utaretulehduksen aiheuttamien tuotosmenetysten arvioinnissa. Tutkimuksessa tarkasteltiin lehmien kuutta ensimmäistä lypsykautta. Laskelmat tehtiin vuoden 2008 hintatasossa.

Keskimääräinen hoitoprosentti (hoitoja/100 lehmää) oli ayrshirelehmillä 30,8 \% ja holsteinfriisiläislehmillä 37,5 \%. Noin 20 \% lehmistä hoidettiin äkillisen utaretulehduksen vuoksi ja noin $10 \%$ umpeenmennessä. Piilevän tai kroonisen utaretulehduksen vuoksi hoidettujen lehmien osuudet olivat vähäisiä. Utaretulehduksen esiintyminen, samoin kuin tulehduksen vuoksi tehdyt eläimen poistot, lisääntyivät lehmän poikimakertojen myötä. Vakavan tulehduksen vuoksi poistettiin lypsykausittain 18 \% lehmistä. Osuus kasvoi noin kaksinkertaiseksi, kun huomioon otettiin kaikki poistot, joiden syyksi karjanomistaja oli ilmoittanut utaretulehduksen.

Tapauskohtaiset utaretulehduksen kustannukset vaihtelivat sen mukaan, mistä lypsykaudesta ja millaisesta tulehduksesta tai hoidosta oli kyse. Jos lehmää ei poistettu tulehduksen takia, menetykset vaihtelivat välillä 270-670 €/tapaus. Jos lehmä hoidoista huolimatta päätyi poistettavaksi, menetykset kasvoivat oleellisesti. Suurimmillaan poiston aiheuttama lisäkustannus oli ensimmäistä lypsykauttaan lypsävillä lehmillä vaihdellen uudistushiehon hinnan mukaan 1560 eurosta 1750 euroon. Utaretulehdukseen sairastuneiden lehmien hoitaminen oli taloudellisempaa kuin niiden korvaaminen ensikolla. Syynä tähän olivat korkeat uudistuskustannukset, maitotuotoksen kasvu lehmän iän myötä ja se, että myös korvaava lehmä tietyllä todennäköisyydellä sairastui utaretulehdukseen.

Mallin avulla voidaan arvioida karjakohtaisia menetyksiä, kun tapauskohtaiset kustannukset painotetaan lehmien jakaumalla lypsykausittain, tulehdustyypeittäin ja lehmän poistotavan mukaan. Tutkimusaineiston mukaisen jakauman perusteella kokonaiskustannus on 100 lehmän karjassa noin $22000 € /$ vuosi. Lehmien kokonaismäärän ja rotujakauman avulla voidaan vastaavasti arvioida utaretulehduksen aiheuttamat kokonaismenetykset. Toukokuun 2009 lypsylehmien määrän perusteella (290 000) kokonaiskustannukset karjanomistajille ovat noin 65 milj. € vuodessa. Utareterveyden parantuminen toisi siten huomattavia säästöjä maidontuottajille, joita kannattavuusongelmat epävakaassa markkinatilanteessa muutoinkin rasittavat.

Asiasanat: lypsykarja, utaretulehdus, dynaaminen optimointi 


\section{Johdanto}

Utaretulehdus eli mastiitti on lypsykarjatalouden vakava ongelma. Suomessa utaretulehdus on sekä lypsylehmien poistojen että eläinlääkärihoitojen yleisin syy. Utaretulehdus heikentää maidon laatua ja eläinten hyvinvointia. Lääkkeiden laaja käyttö utaretulehduksen hoidossa voi aiheuttaa antibioottiresistenttien bakteerikantojen valikoitumista ja vastustuskykyiset bakteerit tai niiden resistenssitekijät voivat edelleen siirtyä myös ihmisiin. Maidontuottajalle utaretulehdus aiheuttaa taloudellisia menetyksiä hoitokustannusten, tuotosmenetysten, lisätyön ja lehmien ennenaikaisten poistojen kautta.

Maidontuottajat kuitenkin usein aliarvioivat utaretulehduksen aiheuttamat kustannukset (Huips ym., 2008). Jotta tuottajilla olisi kannusteita pyrkiä ennaltaehkäisemään tautia, tarvitaan tutkimustietoa utaretulehduksen todellisista kustannuksista. Tieto auttaa arvioimaan myös erialaisten ennaltaehkäisevien toimenpiteiden kannattavuutta niin yksittäisten karjojen kuin koko sektorin tasollakin. Lisäksi tarvitaan tietoa siitä, mikä on taloudellisesti optimaalinen menettelytapa silloin, kun ennaltaehkäisevistä toimenpiteistä huolimatta karjassa esiintyy utaretulehdusta.

Koska tuottajan mahdollisuudet vaikuttaa maidosta maksettavaan hintaan ovat vähäiset, kannattavuuden ja siten kilpailukyvyn parantamiseen on pyrittävä ensisijaisesti kustannuksia karsimalla ja tuotosmenetyksiä ehkäisemällä. Kesällä 2007 mietintönsä jättänyt Utareterveystyöryhmä 2005-2010 arvioi utaretulehduksen aiheuttamien taloudellisten menetysten olevan Suomessa 80-100 milj. euroa vuodessa ja asetti viiden vuoden tavoitteeksi tappioiden karsimisen 20 prosentilla (Maitohygienialiitto 2007). Tämän tutkimuksen tavoitteena oli selvittää utaretulehduksesta maidontuottajalle aiheutuvat taloudelliset tappiot lehmäkohtaisesti ottaen huomioon sekä lehmän ikä että utaretulehduksen tyyppi.

\section{Aineisto ja menetelmät}

Tutkimusongelman ratkaisussa hyödynnettiin Markovin ketjuihin ja Bellmanin optimaalisuusperiaatteeseen perustuvaa dynaamista ohjelmointia (Bellman, 1957; Kennedy, 1986; Bertsekas, 2001). Tutkimuksessa laadittu stokastinen optimointimalli perustui Heikkilän ym. (2008) esittämään lypsylehmien poistopäätösmalliin. Mallilla etsittiin uudistuskäytäntöä, joka maksimoisi lehmän odotettavissa olevan nykyarvon. Erilaisten lehmien arvoja vertaamalla voidaan tehdä päätelmiä tutkittavien ominaisuuksien aiheuttamista taloudellisista menetyksistä.

Dynaaminen ohjelmointi soveltuu päätösten sarjasta koostuviin optimointitehtäviin. Tässä tutkimuksessa ratkaistiin lypsykausittain, kannattaako lehmä pitää vielä tuotannossa vai poistaa ja korvata ensikolla. Lehmän tila kullakin lypsykaudella määriteltiin kolmen muuttujan avulla: poikimakerta (1-6), poistotapa (harkinnanvarainen, pakollinen utaretulehduksen vuoksi, pakollinen muun syyn vuoksi) ja utareterveystilanne (terve, akuutti utaretulehdus, piilevä utaretulehdus, krooninen utaretulehdus, umpihoito). Todennäköisyys saavuttaa seuraavalla lypsykaudella tietty tila määritettiin tutkimusaineistosta jakaumatarkastelun ja logistisen regressioanalyysin avulla. Yhden lypsykauden tuottofunktioon sisällytettiin maito- ja lihatuotto, rehu-, eläinlääkintä- ja uudistuskustannus sekä hukkaan heitetyn maidon, pitkäaikaisten tuotosmenetysten ja geneettisen edistymisen arvo. Muut tuotot ja kustannukset oletettiin kiinteiksi. Malli ratkaistiin äärettömässä aikahorisontissa MATLAB-ohjelman CompEcon-työkalua hyväksi käyttäen (Ljungqvist ja Sargent, 2000; Miranda ja Fackler 2002).

Tutkimusaineisto optimointimallin muuttujien määrittämiseksi kerättiin ProAgrian seurantaaineistoista, hintatilastoista ja aikaisemmista tutkimuksista. ProAgrian aineisto käsitti ajanjakson 1.9.2003-31.8.2005. Aineisto sisälsi tiedot 69490 ayrshirelehmän ja 22789 holstein-friisiläislehmän poikimisista, poistoista, poiston syistä ja utaretulehdukseen liittyvistä hoitomerkinnöistä. Lehmien hoitoprosentti kasvoi poikimakertojen myötä ja oli säännönmukaisesti holstein-friisiläislehmillä hieman korkeampi kuin ayrshirelehmillä (Taulukko 1). Valtaosa hoitomerkinnöistä liittyi akuuttiin utaretulehdukseen ja seuraavaksi eniten hoitoja annettiin lehmien ummessaolokaudella (Taulukko 1). Utaretulehduksen vuoksi poistettiin lypsykausittain 2,8-14,0 \% lehmistä osuuden kasvaessa poikimakertojen lisääntyessä. Holstein-friisiläislehmillä osuudet olivat noin prosenttiyksikön suurempia kuin ayrshirelehmillä. Poistoista noin puolet oli luokiteltavissa pakollisiksi (Nousiainen, 2006). Aikaisempia tutkimustuloksia hyödynnettiin muun muassa lehmien tuotosten ennustamisessa (Lidauer ym., 2000; Lidauer ym., 2003) ja utaretulehduksen aiheuttamien tuotosmenetysten arvioinnissa (Nielsen, 2009). Eläinlääkärihoitojen kustannukset perustuivat Utareterveystyöryhmän esittämiin arvioihin, jotka päivitettiin vuoden 2008 hintatasoon. Myös maidon ja rehujen hinnat olivat vuoden 2008 tasolla. Maidon hinta sisälsi tuotantotuen C2-alueella maksetun tuen suuruisena. 
Taulukko 1. Utaretulehdushoidot lypsykauden ja tulehdustyypin mukaan ayrshire- ja holsteinfriisiläislehmillä.

\begin{tabular}{lcc}
\hline Hoitoprosentti & Ayrshire & Holstein-friisiläinen \\
Keskimäärin & 30,8 & 37,5 \\
Lypsykauden mukaan & & \\
- ensimmäinen & 22,3 & 31,1 \\
- toinen & 30,0 & 37,5 \\
- kolmas & 37,0 & 42,3 \\
- neljäs & 41,4 & 48,6 \\
- viides & 48,2 & 45,5 \\
- kuudes & 40,8 & 45,8 \\
Tulehdustyypin mukaan & 19,8 & 22,9 \\
- utaretulehdus & 2,3 & 3,1 \\
- piilevä utaretulehdus & 0,5 & 0,6 \\
- krooninen utaretulehdus & 8,3 & 10,8 \\
- umpihoito & &
\end{tabular}

${ }^{1)}$ Hoitomerkintöjä/100 lehmää

\section{Tulokset}

Tapauskohtaiset utaretulehduksen kustannukset vaihtelivat sen mukaan, mistä lypsykaudesta ja millaisesta tulehduksesta tai hoidosta oli kyse. Jos lehmää ei poistettu tulehduksen takia, menetykset vaihtelivat välillä 270-670 €/tapaus. Menetykset olivat suurimmat akuutissa utaretulehduksessa ja pienimmät umpeenmennessä hoidetuilla lehmillä. Saman tulehdustyypin kyseessä ollessa menetykset kasvoivat viidennelle lypsykaudelle asti. Syynä oli tuotosmenetysten kasvu lehmien tuotoskasvun myötä. Jos lehmä hoidoista huolimatta päätyi poistettavaksi, menetykset kasvoivat oleellisesti. Suurimmillaan poiston aiheuttama lisäkustannus oli ensimmäistä lypsykauttaan lypsävillä lehmillä, $1560 €$ ayrshirelehmillä ja $1750 €$ holstain-friisiläislehmillä. Rotujen välinen ero johtui uudistushiehon oletetusta hintaerosta. Utaretulehduksen vuoksi poistettujen lehmien hoitokustannukset olivat myös muiden lehmien kustannusta suuremmat, koska hoitoprosentti oli näillä lehmillä suurempi kuin harkinnanvaraisesti tai muun syyn takia ennenaikaisesti poistetuilla lehmillä.

Utaretulehdukseen sairastuneiden lehmien hoitaminen oli taloudellisempaa kuin niiden korvaaminen ensikolla. Syynä tähän olivat korkeat uudistuskustannukset, maitotuotoksen kasvu lehmän iän myötä ja se, että myös korvaava lehmä tietyllä todennäköisyydellä sairastui utaretulehdukseen.

Mallin avulla voidaan arvioida karjakohtaisia menetyksiä, kun tapauskohtaiset kustannukset painotetaan lehmien jakaumalla lypsykausittain, tulehdustyypeittäin ja lehmän poistotavan mukaan. Tutkimusaineiston mukaisen jakauman perusteella kokonaiskustannus oli 100 lehmän ayrshirekarjassa noin $21000 € /$ vuosi ja vastaavasti holstein-friisiläiskarjassa noin $25000 €$ /vuosi. Holsteinfriisiläislehmien paremmista tuotoksista huolimatta eläinpaikan nykyhetkeen diskontattu arvo jäi utaretulehduksen aiheuttamien taloudellisten tappioiden vuoksi holstein-friisiläiskarjassa hieman pienemmäksi kuin ayrshirekarjassa.

Lehmien kokonaismäärän ja rotujakauman avulla voidaan arvioida utaretulehduksen aiheuttamat kokonaismenetykset karjanomistajille. Toukokuussa 2009 Suomessa oli 290000 lypsylehmää, joista noin $67 \%$ oli ayrshirelehmiä, $32 \%$ holstein-friisiläislehmiä ja $1 \%$ muiden rotujen edustajia. Utaretulehduksen aiheuttamat taloudelliset menetykset ovat tällöin noin 65 milj. € vuodessa.

\section{Tulosten tarkastelu ja johtopäätökset}

Kaikki edellä esitetyt luvut on laskettu ottaen utaretulehduksen aiheuttamista lehmien poistoista huomioon vain pakollisiksi luokiteltavissa olevat poistot. Mikäli kustannukset laskettaisiin karjanomistajien ilmoittamien poistojen mukaan, karjatason menetykset olisivat 11-12 \% edellä esitettyjä suuremmat. Vastaavasti, jos utaretulehdus ei aiheuttaisi ollenkaan ennenaikaisia poistoja, karjakohtaiset menetykset pienenisivät 11-14 \%. Säästöt ovat sitä suuremmat, mitä nuoremman lehmän poisto voidaan välttää. Karjanomistajien tulisikin kiinnittää huomiota lehmän ennenaikaisen poiston aikaansaamaan lisäkustannukseen ja pyrkiä mahdollisuuksien mukaan välttämään niitä. 
Laadittu malli antoi tarkastelluilla poikimakerroilla optimipäätökseksi lehmän pitämisen karjassa sen sijaan, että se olisi poistettu ja korvattu poikivalla hieholla. Bar ym. (2008) päätyivät mallissaan samansuuntaiseen tulokseen; 92 \% utaretulehdukseen sairastuneista lehmistä oli taloudellisempaa hoitaa kuin korvata uudella eläimellä. On kuitenkin muistettava, ettei kummassakaan mallissa ollut mukana lehmän muita mahdollisia sairauksia, jotka voivat muuttaa tilannetta etenkin silloin, kun muu sairaus osuu ennestään utaretulehduksen vaivaamalle lehmälle.

Ruotsissa Nielsen (2009) laski kliinisen utaretulehduksen aiheuttaman kustannuksen olevan 275 $€$ ja piilevän $60 €$ per tapaus. Tanskassa Sørensen (2009) laski tapauskohtaisen kustannuksen olevan keskimäärin $231 €$. Tässä tutkimuksessa päädyttiin selvästi suurempiin tapauskohtaisiin kustannuksiin, etenkin jos huomioon otettiin utaretulehduksen aiheuttamat ennenaikaiset poistot. Erilaisten laskentamenetelmien ja -perusteiden vuoksi tämän tutkimuksen tulokset eivät ole suoraan verrattavissa edellä mainittujen tutkimusten tuloksiin. Muun muassa laskelmien pohjana käytetyt uudistus- ja hoitokustannukset olivat tässä tutkimuksessa vertailukohtia suuremmat. Maidon korkeampi hinta ja tuotantotuki nostivat puolestaan tuotosmenetysten arvoa Ruotsissa ja Tanskassa laskettuihin arvoihin verrattuna.

Ei ole realistista olettaa, että utaretulehduksesta päästäisiin kokonaan eroon, mutta jokainen vältetty tulehdus merkitsee maidontuottajalle säästöä, joka on tarpeen epävakauden ja kannattavuusongelmien rasittamassa tuotantoympäristössä.

\section{Kirjallisuus}

Bar, D., Tauer, L.W., Bennett, G., Gonzalez, R.N., Hertl, J.A., Schukken, Y.H., Schulte, H.F., Welcome, F.L. \& Grohn, Y.T. 2008. The Cost of Generic Clinical Mastitis in Dairy Cows as Estimated by Using Dynamic Programming. J. Dairy Sci 91: 2205-2214.

Bellman, R. E. 1957. Dynamic Programming. Princeton University Press, Princeton, NJ. 339 p.

Bertsekas, D.P. 2001. Dynamic Programming and Optimal Control. Volume 2: Dynamic Programming. 2nd edition. Athena Scientific, Belmont, MA. 303 p.

Heikkilä, A-M., Nousiainen, J. I. \& Jauhiainen, L. 2008. Optimal replacement policy and economic value of dairy cows with diverse health status and production capacity. J. Dairy Sci. 91: 2342-2352.

Huips, K., Lam, T.J.G.M. \& Hogeveen, H. 2008. Costs of mastitis: facts and perception. J. Dairy Res. 75:113120.

Kennedy, J. O. S. 1986. Dynamic Programming: Applications to Agriculture and Natural Resources. Elsevier Applied Science Publishers, London, UK. 341 p.

Lidauer, M., Mäntysaari, E. A. \& Strandén, I \& Pösö, J. 2000. Multiple-trait random regression test-day model for all lactations. Interbull Bulletin 25. Proceedings of the 2000 Interbull meeting Bled, Slovenia May 1415, 2000:81-86.

Lidauer, M., Mäntysaari, E. A. \& Strandén, I. 2003. Comparison of test-day models for genetic evaluation of production traits in dairy cattle. Livest. Prod. Sci. 79:73-86.

Ljungqvist, L. \& Sargent, T.J. 2000. Recursive Macroeconomic Theory. MIT Press, Cambridge, MA. 701 p. Maitohygienialiitto 2007. Utareterveystyöryhmä 2005-2010. Mietintö 14.6.2007. Maitohygienialiitto ry. Helsinki.

Miranda, M. J. \& Fackler, P. L. 2002. Applied Computational Economics and Finance. MIT Press, Cambridge, MA. $510 \mathrm{p}$.

Nielsen, C. 2009. Economic Impact of Mastitis in Dairy Cows. Doctoral Thesis. Swedish University of Agricultural Sciences. Uppsala 2009. 81 p. [viitattu 16.11.2009]. Saatavissa

http://diss-epsilon.slu.se/archive/00001968/01/Christel_Nielsen_kappa.pdf

Nousiainen, J.I. 2006. Lypsylehmien poiston syyt. In: Anna-Maija Heikkilä (toim.). Kestävä lehmä. Lypsylehmien poiston syyt ja kestävyyden taloudellinen merkitys. MTT:n selvityksiä 112: 9-26. Verkkojulkaisu päivitetty 2.5.2006. [viitattu 16.11.2009] Saatavissa: http://www.mtt.fi/mtts/pdf/mtts112.pdf

Sørensen, L. P. 2009. Genetic and economic aspects of pathogen-specific mastitis resistance in Danish Holstein cows. Ph.D. thesis. LC 2578. Faculty of Life Sciences, University of Copenhagen and Faculty of Agricultural Sciences, University of Aarhus. 127 p. 